\title{
Games and Fieldwork in Agriculture: A Systematic Review of the 21st Century in Economics and Social Science
}

\author{
J. Nicolas Hernandez-Aguilera ${ }^{1, *}, \operatorname{Max}$ Mauerman ${ }^{1}$, Alexandra Herrera ${ }^{1}$, Kathryn Vasilaky $^{1,2} \mathbb{D}$, \\ Walter Baethgen ${ }^{1}$, Ana Maria Loboguerrero ${ }^{3}{ }^{\mathbb{D}}$, Rahel Diro ${ }^{1}$, Yohana Tesfamariam Tekeste ${ }^{1}$ and \\ Daniel Osgood ${ }^{1}$ \\ 1 International Research Institute for Climate \& Society, The Earth Institute, Columbia University, \\ Palisades, NY 10964, USA; mmauerman@iri.columbia.edu (M.M.); ah3434@barnard.edu (A.H.); \\ kvasilak@calpoly.edu (K.V.); baethgen@iri.columbia.edu (W.B.); rld@iri.columbia.edu (R.D.); \\ yohana@iri.columbia.edu (Y.T.T.); deo@iri.columbia.edu (D.O.) \\ 2 Department of Economics, Orfalea College of Business, California Polytechnic State University, \\ San Luis Obispo, CA 93407, USA \\ 3 CGIAR Research Program on Climate Change, Agriculture and Food Security and International Center for \\ Tropical Agriculture, Cali 760032, Colombia; a.m.loboguerrero@cgiar.org \\ * Correspondence: jnicolas@iri.columbia.edu
}

Received: 9 August 2020; Accepted: 18 October 2020; Published: 23 October 2020

check for updates

\begin{abstract}
Games are particularly relevant for field research in agriculture, where alternative experimental designs can be costly and unfeasible. Games are also popular for non-experimental purposes such as recreating learning experiences and facilitating dialogue with local communities. After a systematic review of the literature, we found that the volume of published studies employing coordination and cooperation games increased during the 2000-2020 period. In recent years, more attention has been given to the areas of natural resource management, conservation, and ecology, particularly in regions important to agricultural sustainability. Other games, such as trust and risk games, have come to be regarded as standards of artefactual and framed field experiments in agriculture. Regardless of their scope, most games' results are subject to criticism for their internal and external validity. In particular, a significant portion of the games reviewed here reveal recruitment biases towards women and provide few opportunities for continued impact assessment. However, games' validity should be judged on a case-by-case basis. Specific cultural aspects of games might reflect the real context, and generalizing games' conclusions to different settings is often constrained by cost and utility. Overall, games in agriculture could benefit from more significant, frequent, and inclusive experiments and data-all possibilities offered by digital technology. Present-day physical distance restrictions may accelerate this shift. New technologies and engaging mediums to approach farmers might present a turning point for integrating experimental and non-experimental games for agriculture in the 21st century.
\end{abstract}

Keywords: review; games; field experiments; participatory processes; agriculture

\section{Introduction}

A game is a system in which players engage in an artificial conflict or problem, defined by rules, resulting in a quantifiable outcome [1]. Games in agriculture fieldwork are designed to test hypotheses, simulate a situation to educate and recreate an experience, or both. Games with experimental and non-experimental purposes are critical in agriculture to understand how individuals process information and make decisions. On the experimental side, field experiments in the form of games are 
increasingly popular. Such studies allow scientists to empirically measure the parameters of theoretical models and lend behavioral insights to policy making discussions [2]. Experimental games are a useful medium of research because they allow scientists to study how context can affect participant behavior, and, unlike observational studies, to construct proper counterfactuals to understand behaviors and social preferences [3,4]. Greater attention to context does not mean, however, that experimental games do not have shortfalls. One of the major concerns with such methods is how results generalize to other contexts and populations - that is, whether they have adequate external validity $[3,5,6]$.

Games with non-experimental purposes, on the other hand, provide innovative ways to accelerate learning and dialogue regarding topics such as economic and physical risk management (e.g., climate variability, natural disasters, and price volatility). These, games help practitioners and researchers from diverse disciplines and sectors involved in humanitarian and development work to communicate more effectively on the field. Well-designed games generate emotional experience while inspiring farmers' behaviors. For instance, games could help build discipline and collective cohesion in preparation for critical decisions [1]. Frequently, these kinds of games do not aim to respond to general questions but assess specific impacts or effects within a particular group. Although some hypothesis might underlie the games, there is not an explicit experimental purpose. In most cases, some metrics for monitoring and evaluation could be carefully designed to assess the impacts of the game within a community where the game has been used systematically [1].

Overall, games can contribute to understanding individuals and groups by mimicking the actual environments and incentive structures where policy interventions and actions will take place. Games are a particularly relevant tool for overcoming obstacles in agricultural research and practice, for example, the long-time frames needed to study agricultural decision making and crop output, or the reaction to catastrophes, by simulating the setup and framing of issues surrounding climate change, food security, biodiversity conservation, governance of natural resources and natural disasters. Despite their ubiquitous use across many disciplines, the mobilization of experimental and non-experimental games has remained surprisingly limited up to now compared to other fields such as consumption, health, employment or the environment [1,7].

Recent literature highlights the relevance and potential of economic experiments as a tool for agricultural policy evaluation [7], and examine a variety of experimental and quasi-experimental approaches that analyze behavioral and risk preferences [8-10]. We are not aware, however, of a systematic literature review of the use of experimental and non-experimental games to advance fieldwork in agriculture, and the extent to which they are helping to inform, educate, understand or predict behavior in specific regions, agricultural sectors and areas of interest. We fill this gap by formulating clear questions and criteria to select, identify and analyze relevant studies and by proposing how games can be used to pursue future research and to enhance communication and dialogue.

\section{Questions}

The overarching goal of this study is to analyze the existing literature on games and agriculture between 2000 and 2020 to characterizes their focus and scope, and understanding their strengths, weaknesses and improvement opportunities. To this end, we lead with three questions:

- Q1: What is the primary purpose and context of games in agriculture in this period?

- Q2: What is the scope of the game's results and conclusions based on the experimental/setting design?

- Q3: Is there evidence of any technological transition or evolution in the way that games have been performed and implemented in rural areas?

In general, Q1 requires identifying the subjects and the context of each game, including the specific agricultural sector involved and the behavioral test or purpose behind the game. Q2 is designed to assess how robust, and replicable a game's results and conclusions are. Finally, Q3 analyzes 
the experimental design and technological elements that affected games' scalability, accessibility, replicability, and costs.

\section{Methods}

In this study, we present a systematic literature review (SLR) based upon a pre-determined rubric to evaluate each study. The SLR followed suggested PRISMA guidelines for preferred reporting items [11]. We searched electronic databases in June 2020, including the Web of Science (WS) and Scopus, the largest databases of peer-reviewed literature with multidisciplinary coverage of academic articles [12,13]. To limit the scope of the review, we defined full and truncated search terms capturing experiments, games, and agriculture in the following general search strings on the title, abstracts or keywords: (game* OR experiment* OR test* OR behavior* OR gamif*) AND (agriculture OR farm* OR smallholder).

This first screening layer included peer-reviewed articles published in English from 2000 to the present (WS: 78,440 and Scopus: 118,016). We refined the search based on Scopus subject area filter, including social science, economics, business and psychology (Scopus), and the closest WS categories, which included economics, agricultural economics policy, business, behavioral science, and interdisciplinary social science. As a result, WS suggested 3824 references while Scopus suggested 11,265 . These numbers indicate that even if all WS references were duplicated, our first refined search suggested more than ten thousand references (Figure 1).

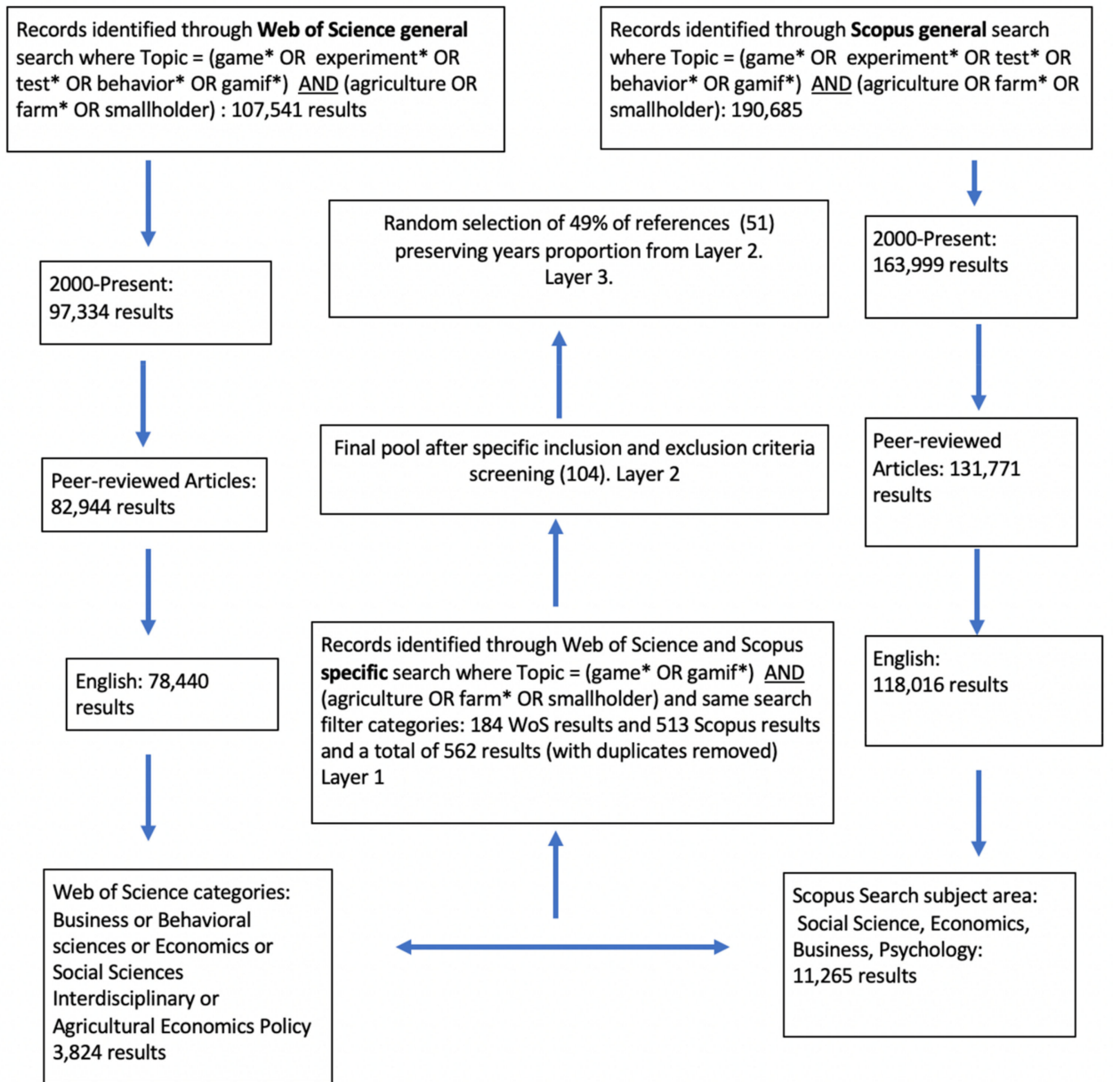

Figure 1. Systematic literature review and screening process.

Given this large number of papers, we refined our search and were more specific on the first component of the search string, including only (game* OR gamif*). Consequently, we defined the new 
string as (game* OR gamif*) AND (agriculture OR farm* OR smallholder). As before, we completed the search based on the title, abstracts, or keywords. As a result, WS suggested 184 references while Scopus 513. We then removed 135 duplicates, consolidating a final pool of 562 references (layer one).

We improved our first layer screening according to the following inclusion criteria: (i) well-explained research or implementation methods, (ii) explicitly stated and described game/experiment/test, (iii) impact or effect reported and iv) clearly described outcome related to farmer behavior or decision making. For the second layer of screening, we excluded references following these criteria: (i) economic models with game theory but without any fieldwork, tests or experiments conducted with farmers; (ii) surveys or interviews without activities, games, tests or experiments (even when fieldwork or visits occurred); (iii) publications with mixed methods, which included critical perspectives, protocols, personal observation, and reviews but no experimental or game design, nor interactions with farmers; (iv) studies that used the word "game" in a different context (i.e., wild animals hunted); (v) studies on animal (non-human) behavior; and (vi) lab experiments and games with subjects other than farmers to simulate "rural contexts" or farmers (mentioned in the following section). As a result, layer two concluded with a pool of 104 references- $46 \%$ were from Scopus, $50 \%$ were from Web of Science and $4 \%$ were found in both.

To review the papers in a systematic way, we defined specific categories that demanded different levels of analysis. The basic level included direct metrics such as the agriculture sector or the number of participants. The higher level included a more detailed assessment and judgment of the experimental design. This comprehensive analysis required a careful reading of 51 papers that were randomly selected in proportion to the papers found for each year in layer two. Proportions were preserved to reflect the trend in topics and the ratio of publications across time. The number of articles analyzed is comparable to previous reviews on agricultural economics experiments that range from 35 to 51 articles analyzed. The latter include lab experiments, discrete choice experiments, and field experiments [8-10]. Of the 51 articles analyzed by the authors in this review, 45\% were from Scopus, $51 \%$ from Web of Science and $4 \%$ were found in both.

\section{Categories}

Game-based field experiments lie on the bridge between laboratory and the real world naturally occurring data [3]. Lab experiments employ a standard pool of participants (students), an abstract framing, and an imposed set of rules. Artefactual field experiments (AFE) are the same as a conventional lab experiment, but participants are not students but individuals participating in the field environment of interest [9]. Framed field experiments (FFE) move a step closer to a naturally occurring setting, including the field and context of participants in either the commodity, task, or information set that users can use [4]. Finally, natural field experiments are similar to FFE, but participants are performing their everyday decisions in their natural environment without knowledge that they are being observed [3,4]. Since our main goal is to capture real-life contexts and decision making, our review considers mainly field experiments and games that can be mainly classified as AFE and FFE. In addition, as we anticipated that a significant portion of the games occur in low- and middle-income regions, with significant income and education differences between students and farmers, we exclude games where students assumed the role of farmers [14]. These kinds of experiments involving farmers (as opposed to students) are also more likely to be considered by policy makers [8].

In their attempt to better communicate and reach the target populations, non-experimental games adopt different formats. They usually have an explicit and carefully thought-out educational purpose (serious games). They can also expand from the domain of the game to the domain of ordinary life (pervasive games), and engage farmers in experiencing complex systems to better understand their role transforming that system (inhabitable games) [1]. All these categories were considered in the review as long as they were filling the inclusion criteria and were not limited to prototypes, case studies or interviews without farmers active enrollment. 
To characterize the games being studied, we defined four thematic domains. Social preferences included games measuring altruism, reciprocity trust, fairness, and subjects' behavior and attitudes toward others' wellbeing. Coordination and cooperation games included canonical and non-canonical experiments of public good games, common pool resources dilemmas, and governance challenges. Market games and simulations included games that mimic the rules of various real-world market institutions (e.g., auctions and insurance) and that measure willingness to buy or sell different products and services. These three domains encompassed strategic interactions and thinking among individuals and groups. The final domain, behavioral and cognitive bias included games focused on individual decision making, behavior, and capacities, specifically risk preferences and attitudes, memory, intertemporal behavior and discounting, and adoption and learning of new technologies. Agricultural sectors, when defined, were classified by growing crops, raising animals, fishing, hunting, and forestry. Moreover, we identified the context in which games took place to determine the areas where recommendations and conclusions apply, specifically farm risk (climate risk, financial and market risk, and pest and diseases), conservation and natural resource management (land, water, biodiversity), inclusion and poverty (gender, ethnicities, food security, health), and networks and social capital formation (including formal and informal institutions, organizations, and regulations (Table A1).

We defined specific categories to assess the scope, validity, and robustness of the games. Some of these categories involved direct metrics, while others required some level of judgment. Direct metrics included (i) the number of participants; (ii) the number of rounds and/or repetition of the game; (iii) the report of a balanced sample in terms of gender, age and ethnicity of participants; (iv) the monetary and non-monetary incentives (real and simulated); and (v) the presence of power calculations, which can shed light on whether a study has a sufficient number of participants to detect an effect, and the validity of any detected effect sizes [15].

We judged the robustness of each study's findings based on whether the experimental design considered credible counterfactuals and/or accounted for the potential existence of confounding factors. We also evaluate the technologies used to collect data and whether there was a possibility for continued data collection and impact assessment. We considered metrics that reflect how personalized the data collection process was including (i) the identification of the facilitator (i.e., researcher, local collaborator, or digital tool), (ii) the modality or interface (i.e., paper based, cell or smartphone web-based software) of the game and (iii) the player's possibility of sharing the game with other members of their community. We reviewed each paper based on the above standardized categories, and we cross-checked codes for internal consistency. We cleaned, analyzed, and graphed the data in R.

\section{Descriptive Statistics and Results}

Over the last twenty years, there has been a significant increase in the volume of publications related to games in agriculture. Approximately two-thirds (67\%) of these studies were intended as experiments to measure some kind of generalizable principle, such as an aspect of economic behavior or a policy effect. Half of these experimental games were classified as artefactual field experiments while the other half corresponded to framed field experiments. The remaining $33 \%$ of studies involved games where context-specific cases answered questions such as how a particular community interacted with serious games.

Games were conducted mainly in Asia, Sub-Saharan Africa, and Latin America in the context of growing crops and, more recently, on forestry and livestock (Figure 2). In general, activities studied became more diverse over time. For example, over the last 15 years, games were used for solving issues within conservation, ecology and farm risk management issues (Figure A3). There was also a clear increase in studies evaluating group and collective decisions beyond individual behaviors (Figure A4). We found relatively fewer studies with games conducted in North America, Europe or Australia, but there was a steady increase in the use of games in those regions after 2010. In terms of 
topic, coordination and cooperation games were the most frequent worldwide, and most prevalent in Sub-Saharan Africa and Europe (Figure 2).

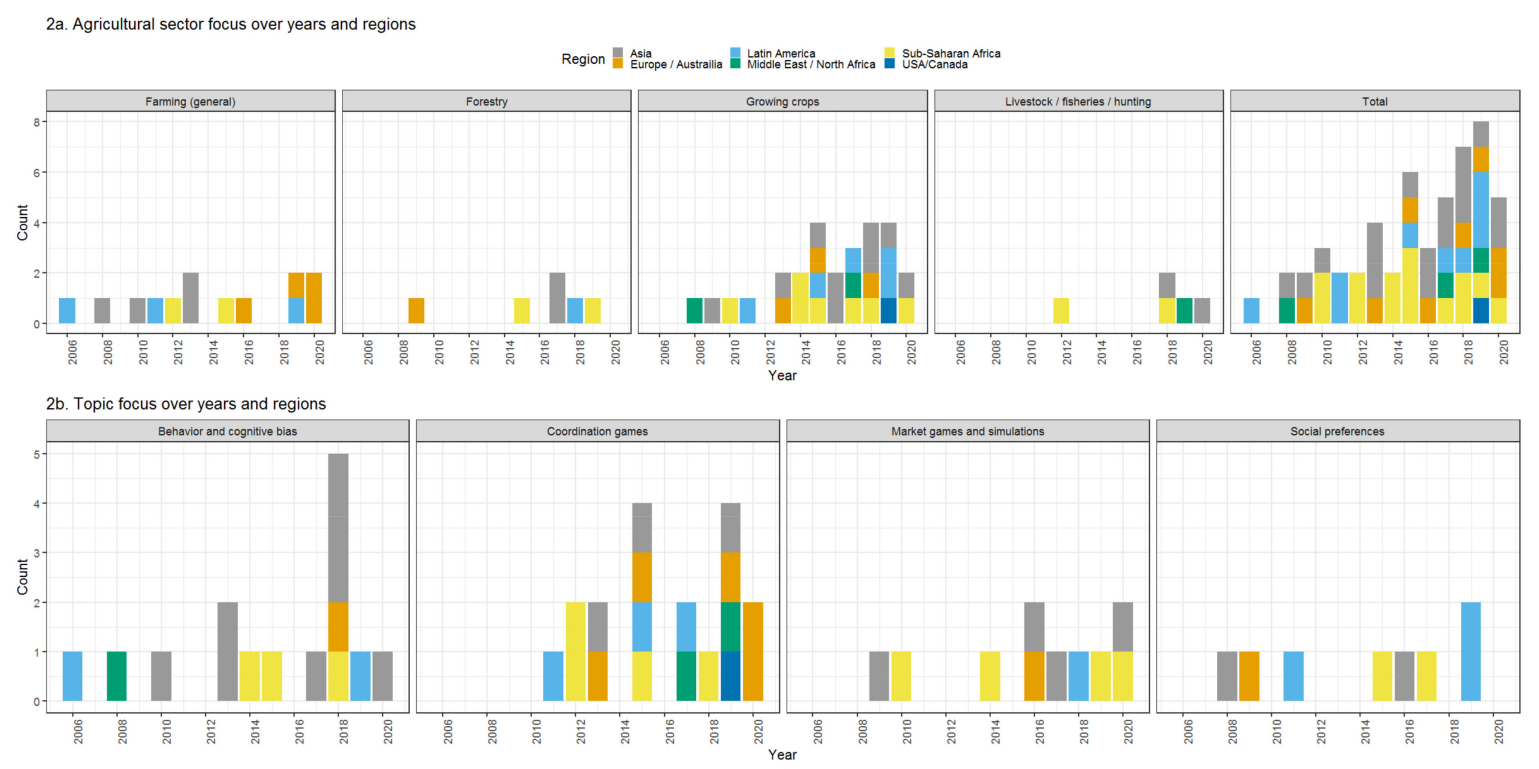

Figure 2. Domain and frequency of studies by the agricultural sector, topic and region. Games were more frequent in Asia, Sub-Saharan Africa, and Latin America, and mainly involved coordination and cooperation. Social preference games were specially oriented to measure trust, while behavioral and cognitive bias games focused on risk preferences and attitudes (Figures A1 and A2).

Regarding the scope and validity of the games, the majority of studies either did not report or were not balanced on gender, age and ethnicity, and very few reported power calculations for establishing sample size (Figure 3, red). Breaking the sample down by study focus, studies of individual preferences and behaviors had a larger sample size, and they were more gender-balanced than studies of cooperation and coordination, and games related to market simulations. However, individual behavior studies were also much less likely to have repeated follow-up studies over time or use real monetary incentives (Figure 3, red). Studies of cooperation and coordination were judged with the lower level of causal validity, and studies of market games and simulations were more likely to have confounding factors (Figure 3, blue).

Of the 46 studies that recorded survey modality, only 7 (15\%) were digital (web-based, computer or tablets), and the remaining $39(85 \%)$ were paper-based. Similarly, out of 51 studies, $78 \%$ reported no data gathering after the initial intervention or experiment, and $71 \%$ reported having no mechanism for participant feedback over time. Approximately $30 \%$ of the games incentivized participants with actual monetary rewards, while only $17 \%$ were associated with intrinsic motivations. The remaining $52 \%$ used simulated/hypothetical monetary rewards.

Regarding the results of the papers reviewed, Table 1 summarizes key findings by topic and scope (as defined above). For instance, a body of evidence suggests that contribution to public goods is greater in smaller and more familiar settings, and that the efficacy of policies to promote environmental public goods depend on their design. Another consistent finding in the literature is that small, self-policing organizations exhibit more cooperative behavior, and that individual incentives influence cooperative behavior. In the area of market games and simulations games, multiple papers find that that markets for environmental goods are sensitive to design choices, and playing games that educate people about financial instruments can eventually affect demand. Behavioral and cognitive bias games show that extrinsic motivators do not appear to crowd out intrinsic motivations. Moreover, risk games suggest that preferences revealed through games often reflect real-world risk factors. Finally, social preference games reported in this review suggest that familiarity with neighbors leads to more pro-social behavior; 
social trust influences technology adoption; trust influences farmers' willingness to participate in potentially risky social actions; and scarcity is not always an explanation for anti-social behavior.

3. Average research scope by topic studied (blue $=$ subjective measures)

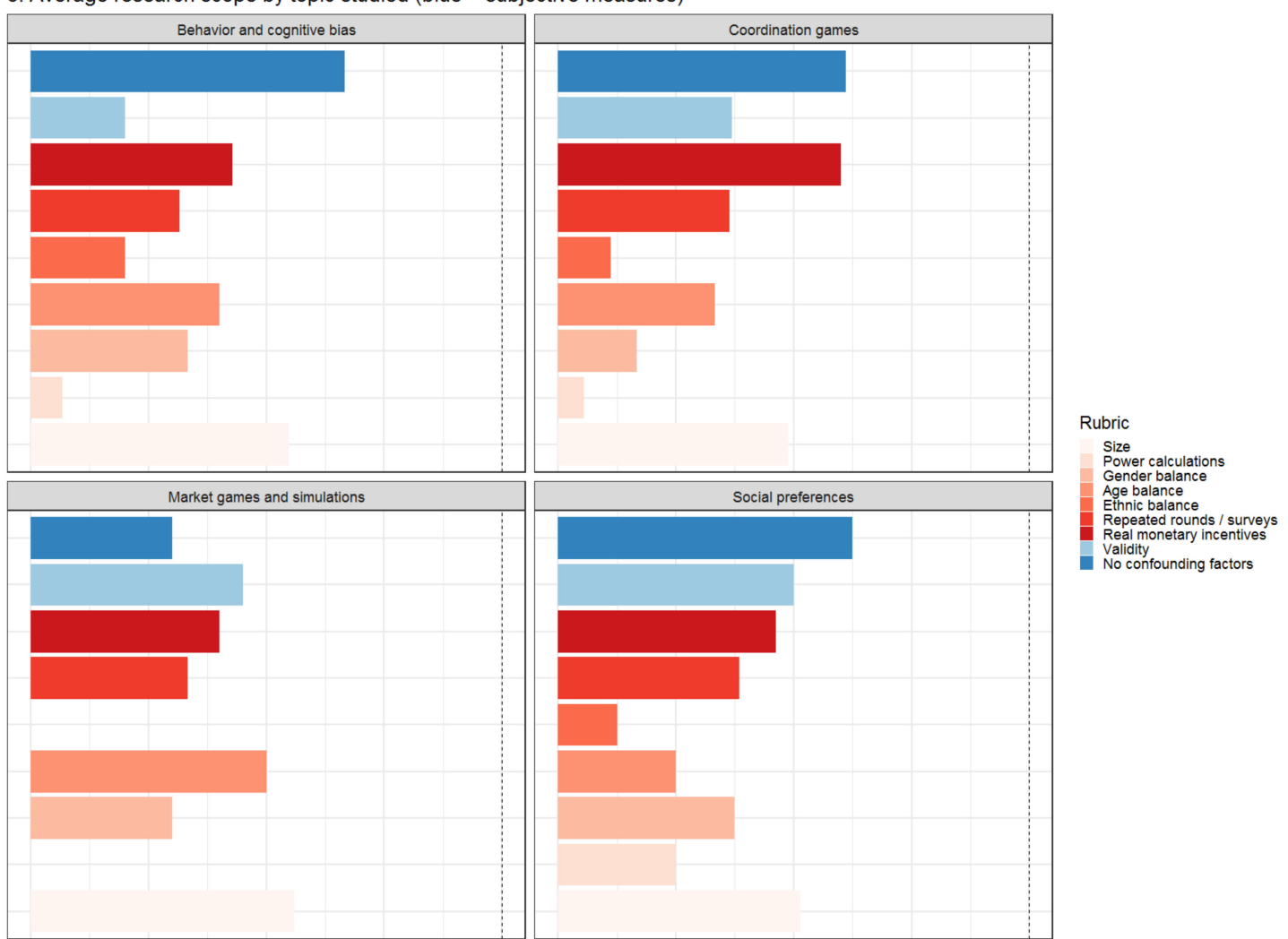

Figure 3. Average research scope by topic. Blue represents measures that required reviewers' judgment. Variables representing aspects of research quality were transformed into a $0-1$ scale for comparability (see Appendix A, Table A2 for the coding scheme). 
Table 1. Major results summary by topic and scope.

\begin{tabular}{cc}
\hline & Scope ${ }^{*}$ \\
\hline Above Median Score (1.3) & Below or in the Median Score (1.3) \\
\hline$n=25$ & $n=26$ \\
\hline$n=10$ & Coordination and Cooperation Games $(n=19)$ \\
\hline Public good games $(n=3):$ Contribution to public goods is greater in & $n=9$ \\
\hline
\end{tabular}

\section{Public good games $(n=3)$ : Contribution to public goods is greater in}

\section{smaller, more familiar settings: A natural experiment in Sri Lanka [16}

finds that members of larger farming communities were less willing to

contribute to a public goods game.

The efficacy of policies to promote environmental public good

depends on their design: A simulation game with farmers in

Europe [17] finds that action-based incentives (i.e., rewards for

individual planting behavior) were more effective at promoting

biodiversity conservation than results-based incentives (i.e., rewards for

collective biodiversity outcomes).

However, game actions may not always predict actual public goods

behavior: An observational study in Sierra Leone [18] finds that

behavior in a public goods game had no meaningful correlation with

actual pro-social behavior in a community development program.

Coordination and cooperation games $(n=7)$.

Small, self-policing organizations exhibit more cooperative behavio

In the Philippines, a study finds evidence that farmers' common-pool

game contributions depended on their neighbors' actions [19]. Similarly

a study in the Republic of Congo [20] finds that self-monitoring reduced free riding in a common pool game.

Individual incentives influence cooperative behavior: A study in the US finds that farmers' propensity to cooperate in a game depended on their degree of risk aversion and their expectation of others

behavior [21]. A study in Germany finds that a social nudge reduced farmers' free riding in a simulation game [22]. Likewise, a study in Latin America finds that individual incentives were more effective than

collective incentives in promoting cooperation in an ecosystem services simulation [23].

In the Philippines, a study finds that women and men had almost equal

Public good games ( $n=1)$ : An observational study of coffee farmers in Costa Rica [26] finds that farmers from different communities

contributed less to a public goods game than farmers from the same ity and that free-riding behavior was correlated with actu -riding behavior

Coordination and cooperation games $(n=7)$ :

Five of these studies were descriptions of serious games without quantitative hypothesis tests (only qualitative accounts of participants' actions and feedback).

A study in South Africa and Namibia finds that contributions to a common-pool resource game were greater in homogenous

sociodemographic settings [27]. An observational study across communities in the Levant finds that farmers from places with a simulation game, as compared to farmers from places with top-down water management systems [28].
Above median

Sawada et. al. (2013) [16]; Voors et. al. (2012) [18];

Doerschner and Musshoff (2015) [17]; Francesconi et al. (2015) [25]

Hayo and Vollan (2012) [27]; Marrocoli et al. (2018) [20];

dler et. al. (2015) [23];

Peth and Musshoff (2020) [22];

Singerman and Useche (2019) [21]

Tsusaka et al. (2015) [19];

Maligalig et. al. (2019) [24]

\section{Below median}

Hopfensitz and Miquel-Florensa (2017) [26]

Msaddak et al. (2019) [29];

Bare en

Cele et al. (2017) [28];

Garcia-Barnos (2011) [31]

Hardy et. (2020) [33];

Sausse et. al. (2013) [34]

decision-making power in an intra-household farm investment

simulation [24].

Behavior in games can be a good proxy of farming organizations

financial health: An observational study in Ghana [25] finds that the

financial performance of farmer cooperatives in Ghana was correlated

with its members' behavior in a risky dictator game. 
Table 1. Cont.

\begin{tabular}{|c|c|c|}
\hline \multicolumn{2}{|c|}{ Scope * } & \multirow[t]{2}{*}{ References } \\
\hline \multicolumn{2}{|r|}{ Market Games and Simulations $(n=10)$} & \\
\hline Above Median Score (1.3) & Below or in the Median Score (1.3) & \\
\hline$n=2$ & $n=8$ & \\
\hline $\begin{array}{l}\text { Markets for environmental goods are sensitive to design choices: } \\
\text { A RCT in Liberia, using a simulation game, finds that monetary } \\
\text { incentives to reduce fertilizer usage were more effective when they were } \\
\text { framed as punishments rather than rewards, but less sustainable [35]. In } \\
\text { contrast, a RCT in Tanzania [36] finds that PES was more effective in } \\
\text { improving forest conservation than mandated levels of contribution } \\
\text { (backed by penalties). }\end{array}$ & $\begin{array}{l}\text { Insurance demand ( } n=3 \text { ): A study in India finds that the average } \\
\text { willingness to pay for weather insurance was approximately 9\% of } \\
\text { the maximum possible payout, and that demand was greater for } \\
\text { the group as compared to individual insurance [37]. A simulation } \\
\text { in Ethiopia finds that farmers exhibited a preference for insurance } \\
\text { over other risk management options, including high-interest } \\
\text { savings [38]. A RCT in Ethiopia finds that playing an educational } \\
\text { game increased uptake of index insurance by } 10 \% \text { [39]. In contrast, } \\
\text { a RCT in Ethiopia and Malawi finds that games and conventional } \\
\text { training practices were equally effective in inducing demand for } \\
\text { insurance [40]. } \\
\text { Payment for environmental services ( } n=2 \text { ): A study in Indonesia [41] } \\
\text { finds that longer-established farmers and those with larger plots } \\
\text { were more likely to win PES auctions. Actual conservation } \\
\text { compliance cost was about } 115 \% \text { greater than the bid outcome on } \\
\text { average, and only about } 55 \% \text { of farmers completed their contracts. } \\
\text { A qualitative study in Latin America finds that the implementation } \\
\text { of PES schemes often rests on deep-seated power asymmetries and, } \\
\text { therefore, risks reproducing existing inequalities [42]. } \\
\text { Other }(n=2) \text { : Two remaining studies were descriptions of } \\
\text { participatory design processes without any quantitative hypothesis } \\
\text { tests (only qualitative accounts of participants' actions } \\
\text { and feedback). }\end{array}$ & $\begin{array}{l}\text { Above median: Moser and Musshoff (2016) [35]; } \\
\text { Kaczan Swallow and Adamowicz (2019) [36]. } \\
\text { Below median: } \\
\text { Vasilaky et al. (2020) [39]; } \\
\text { Norton et al. (2014) [38]; Leimona and Carrasco (2017) [41] } \\
\text { Berthet et al. (2016) [43]; } \\
\text { Bos et al. (2020) [44]; } \\
\text { Merlet et al. (2018) [42]; } \\
\text { Seth et al. (2009) [37]; } \\
\text { Patt et. al. (2010) [40]. }\end{array}$ \\
\hline
\end{tabular}


Table 1. Cont.

\begin{tabular}{|c|c|c|}
\hline \multicolumn{2}{|c|}{ Scope * } & References \\
\hline \multicolumn{3}{|c|}{ Behavior and Cognitive Bias $(n=15)$} \\
\hline Above Median Score (1.3) & Below or in the Median Score (1.3) & \\
\hline$n=7$ & $n=8$ & \\
\hline $\begin{array}{l}\text { Extrinsic vs. intrinsic motivators: }(n=2) \text { Extrinsic motivators do not } \\
\text { appear to crowd out intrinsic motivations: A study in Germany [45] } \\
\text { finds that both direct individual nudges and social comparisons reduced } \\
\text { farmers' illicit fertilizer use in a simulation game, but that combining the } \\
\text { two did not lead to any additional effect. Likewise, a study in } \\
\text { Colombia [46] finds that PES did not change farmers' self-reported } \\
\text { motivations for conservation, and that PES improved conservation } \\
\text { behavior in a simulation game, regardless of its design (i.e., individual } \\
\text { vs. collective payments). } \\
\text { Risk preferences/attitude: }(n=5) \text { Risk preference revealed through } \\
\text { games often reflect real-world risk factors: A study in Paraguay [47] } \\
\text { finds that when the risk of theft is higher, the amount of gift-giving } \\
\text { increases and that risk attitudes are highly predictive of play in } \\
\text { behavioral games. Similarly, [48] finds that risk-averse farmers are less } \\
\text { likely to invest, even with insurance available. A study in Vietnam [49] } \\
\text { find that low-wealth farmers reduce their fertilizer intensity when their } \\
\text { risk aversion increases, and the marginal effect of risk aversion is } \\
\text { insignificant for high-wealth farmers. } \\
\text { Risk preference findings have implications for the "poverty trap" } \\
\text { model of development: A study in Ghana [50] finds that farmers are } \\
\text { more concerned with maximizing agricultural productivity than } \\
\text { minimizing variance. }\end{array}$ & $\begin{array}{l}\text { Addressing Issues of power asymmetry }(n=1) \text { : One study [51] finds } \\
\text { that the use of games for collective decision making can encourage a } \\
\text { greater socioeconomic variety of farmers to voice their opinions. } \\
\text { Risk preferences/attitude: ( } n=4) \text { [52] looks at risk aversion in farmers } \\
\text { vs. freelancers and finds that farmers were more risk-averse than the } \\
\text { freelancers. However, both groups exhibited constant partial risk } \\
\text { aversion and decreasing absolute risk aversion. Ref. [53] finds that } \\
\text { most farmers preferred cash payments when given a choice to index } \\
\text { insurance contracts, even when the insurance contracts offered } \\
\text { substantially higher expected returns. Ref. [54] finds that it is more } \\
\text { important to consider a farmer's situation, information available, } \\
\text { and the emotional state to predict risk aversion than assume a fixed } \\
\text { attitude among all farmers. } \\
\text { Different measurements of risk preferences may yield inconsistent } \\
\text { results: [55] finds that the elicitation technique chosen influences the } \\
\text { degree of farmers' measured risk aversion. } \\
\text { Games and technology adoption ( } n=3 \text { ): Games can be a useful tool for } \\
\text { facilitating technology adoption: [56] finds that farmers who played } \\
\text { a serious game about shrimp farming increased information } \\
\text { exchange with peers, and consequently, increased the likelihood of } \\
\text { technology adoption. } \\
\text { However, games' abstraction can limit their applicability: [57] finds } \\
\text { that participatory scenario development was better suited for } \\
\text { farmers' collective decision-making processes than role-playing } \\
\text { games, which farmers found to be more abstract. } \\
\text { Group composition and individual identity influence productive } \\
\text { technology adoption: [58] finds that women have a stronger } \\
\text { preference for agroforestry, and male-only groups prefer more } \\
\text { production (timber) and protection forest. Ref. [59] looks at group } \\
\text { size and leadership and finds that smaller groups promote more } \\
\text { coordination, but leading by example, did not improve coordination. }\end{array}$ & $\begin{array}{l}\text { Above median: } \\
\text { Brick et al. (2015) [48]; } \\
\text { Khor et al. (2015) [49]; } \\
\text { Katic et al. (2018) [50]; } \\
\text { Schechter et al. (2006) [47]; Mueller et al. (2018) [47]; } \\
\text { Moros et al. (2019) [46]; Peth et al. (2018) [45]. } \\
\text { Below Median: } \\
\text { Barnaud, C. et al. (2010) [51]; } \\
\text { Ye et al. (2013) [52]; Marenya et al. (2014) [53]; } \\
\text { Lebel et al. (2018) [54]; } \\
\text { Dionnet et al. (2008) [57]; Bosma et al. (2020) [56]; } \\
\text { Nielsen et al. (2013) [55]; Villamor et al. (2017) [58]. }\end{array}$ \\
\hline
\end{tabular}


Table 1. Cont.

\begin{tabular}{|c|c|c|}
\hline \multicolumn{2}{|c|}{ Scope * } & \multirow[t]{2}{*}{ References } \\
\hline \multicolumn{2}{|r|}{ Social Preferences $(n=7)$} & \\
\hline Above Median Score (1.3) & Below or in the Median Score (1.3) & \\
\hline$n=6$ & $n=1$ & \\
\hline $\begin{array}{l}\text { Altruism }(n=1) \text { : Familiarity with neighbors leads to more pro-social } \\
\text { behavior: A quasi-experimental study in Cambodia (exploiting a } \\
\text { resettlement lottery) finds that resettled farmers gave } 42-75 \% \text { less to } \\
\text { their neighbors in a solidarity game [60]. } \\
\text { Trust }(n=4) \text { : Social trust influences technology adoption: An RCT in } \\
\text { Ecuador finds that receiving agricultural advice from an extension agent } \\
\text { led to greater trust (as measured by a trust game) and greater learning } \\
\text { than when advice was given by a neighbor [61]. Likewise, two separate } \\
\text { observational studies in Ethiopia find that behavior in a trust game was } \\
\text { correlated with actual soil conservation behavior [62,63]. } \\
\text { Trust influences farmers' willingness to participate in potentially } \\
\text { risky social actions: A study in Ecuador finds that delayed loan } \\
\text { repayment led farmers to trust their partners less (as measured by a trust } \\
\text { game), and consequently made them less willing to loan money in the } \\
\text { future [64]. } \\
\text { Other }(n=1) \text { : Scarcity is not always an explanation for anti-social } \\
\text { behavior: A study in Latin America finds that farmers' cheating } \\
\text { behavior in a multi-round game did not depend on their current level of } \\
\text { scarcity in the game [65]. }\end{array}$ & $\begin{array}{l}\text { Other }(n=1) \text { : A study in Cameroon finds that "knowledge elicitation } \\
\text { tools" (semi-structured interviews with a game component) were an } \\
\text { effective method for measuring farmers' attitudes toward } \\
\text { conservation [66]. }\end{array}$ & $\begin{array}{l}\text { Above median: Gobien and Bjoern (2016) [60]; } \\
\text { Aksoy and Palma (2019) [65]; } \\
\text { Bouma et. al. (2008) [62]; Buck and Alwang (2011) [61]; } \\
\text { Romero and Wollini (2019) [64] } \\
\text { Ansink et al. (2017) [63]. } \\
\text { Below median: } \\
\text { Bharwani et al. (2015) [66]. }\end{array}$ \\
\hline
\end{tabular}




\section{Discussion}

The prevalence of games used for testing behavioral hypotheses $(67 \%)$ compared to games with educational but non-experimental purposes $(33 \%)$ reflects researchers' preference toward studies that allow generalizing in some way the results found on the field. This concern is legitimate, as experiments attempt better to inform policies and improve their design and implementation $[7,9]$. Indeed, the increasing number of framed field games and experiments in rural Asia, Africa, and Latin America during the last twenty years have contributed to filling the information and modeling gaps that characterize socioeconomic and environmental research in agriculture for those regions. However, such causal studies often ran up against the practical difficulties of conducting fieldwork, especially in rural contexts. Most games suffered in establishing whether their findings uncovered causal effects for the population and the specific context being studied—that is, internal validity-as well as whether game behavior reflected real-world decision making in other contexts-that is, external validity. In addition, a significant portion of the experiments showed potential recruitment biases with little participation by rural women who are usually excluded from social gatherings and activities $[4,67]$. Furthermore, spatial and temporal limitations on the scope of results were evident, as the games we surveyed were predominately one-time interventions with no repetition, and no power tests were performed to define the optimal sample size. Overall, the intention of games to produce generalizable results to inform policies is threatened by systematic exclusion of population segments, difficulties in tracking information and results over time, and a lack of large, representative samples. Those challenges are especially complex when conducting fieldwork in rural areas.

Framed field experiments, if conducted well, can fill evidence gaps left by other popular methods of empirical social science. For instance, while randomized control trials (RCTs) of policies are often considered the gold standard for internal validity [68] (and "natural experiments" a next-best alternative [2,3]), they are only part of the field experimenter's toolkit, and cannot always speak to external validity [3]. There are many situations in which natural experiments and RCTs have gaps in their ability to inform policy. For instance, researchers cannot generate natural experiments but must work with the exogenous events that have occurred, hopefully discovering an event that provides identification. Likewise, RCTs can require scaling and experimental designs that are economically and ethically infeasible in many situations [6,69]. Thus, field experiments and games have an essential and unique role in advancing research in agriculture. The right approach should be to find innovative ways to improve validity subject to fieldwork limitations and opportunities.

Ideally, a robust field experiment design should consider power calculations to define the optimal sample size as well as other mechanisms that guarantee research transparency and traceability, including pre-registration of analysis plans [70]. Additional protocols should also include "home" and local institutional review boards, survey data to better characterize participants, and sufficient cash and funds to compensate participants according to their preferred payment methods [9]. Most of the time, however, those desirable standards clash with the realities in the field. Specifically, the lack of effective mechanisms to track participants over time in rural settings reduces the possibility of generating additional and more frequent information. In brief, universal protocols are challenging to implement when the communication infrastructure does not exist, and the real possibilities to advance and track the fieldwork process and results are limited. These common gaps reflect structural and technological limitations to improve validity and scale research and games.

Some limitations to improve games' validity are not necessarily structural and can be addressed through innovative game design strategies. For instance, one-third of the games' took advantage of real money pay-offs to better simulate actual decision-making contexts. Financial incentives equivalent to what participants' economic gains could have been in a real-life setting ensure that individuals in the experiment reveal their true preferences [7]. Most, but not all, participants received a payment in the studies that we reviewed. Some payments were randomly assigned to reduce the costs of the experiments. For instance, in the case of experiments that featured multiple rounds of games, one binding round was randomly selected to ensure that participants would receive a real return 
without compromising the experiment budget [24]. In brief, judging an experimental design requires understanding when the limitations compromise-or not-validity on a case-by-case basis.

Bias towards generalizable results also has a downside. For instance, gender imbalance or specific cultural aspects might reflect, in practice, the real context where individual and collective decisions are made, and behaviors shaped. The predictive value of the games' findings in a different context - the external validity-should be judged according to the diversity and complexity observed in agricultural systems worldwide, and the policy and project goals associated with a specific game. Not surprisingly, we found that some papers suggested that behavior in games did not reflect behavior in the presence of actual programs [38,55]. In contrast, for other studies, there was evidence that behavior in experimental settings correlated with real-world behavior [20,71-74]. The ambiguity in external validity raises questions regarding the need (and the costs) of generalizing conclusions and policy recommendations and highlights the importance of considering each study's relative strengths and weaknesses. Depending on the objective, it could be justifiable to sacrifice external validity and generalization in defense of context-based responses sensitive to local social norms and culture [7]. In brief, there are clear opportunities to improve internal validity and identification strategies in most of the games. However, validity needs to be judged according to the context of each game. The gold standard should be the best method for the question at hand and not a universal approach [69].

Games in agriculture could benefit from more significant, frequent, and inclusive information. However, games are neither effective nor efficient in many settings due to the costs of visiting remote villages and the limited number of facilitators and participants. Scalability will likely improve in the coming years with the increasing digital connectivity among agricultural practitioners [75]. Digital tools can expand the frequency and sample size compared to games conducted on paper-based forms. For example, researchers can use mobile applications (e.g., ODK) to input responses offline and make data cleaning and analysis more efficient. [46]. More sophisticated tools have been developed, targeting extensionists and technicians to reach farmers [76]. Europe, Australia, and the USA showed a moderate, but increasing use of games, especially with the aid of innovative interfaces and technologies $[7,17,22,45]$. Furthermore, initial pilots and proposals also point to the possibility of using gamification-defined as the use of game design elements in non-game contexts-in agriculture through websites, apps, and SMS [77-80]. By definition, gamification is at the intersection of serious games, persuasive technology, and personal informatics [81-83]. These components educate, incentivize, and track players' behavior simultaneously. Overall, gamification provides an opportunity to integrate experimental and non-experimental purposes in a single game while enhancing the learning experience and scaling the data to test hypotheses and generalize results.

Technologies of this century can expand the scope and validity of games in agriculture. However, the low level of digitalization among the papers that we surveyed shows that this integration is still underdeveloped compared with other sectors [81]. The integration of new technologies and games will require better connectivity conditions and researchers with the skills to make this happen. The lack of investments and fixed costs of new technologies can undoubtedly constrain digital tools and games in agriculture in less developed regions. Nonetheless, 70 percent of the poorest 20 percent in low- and middle-income countries have access to a mobile phone, and one in three people have internet access [84-86]. Although connectivity prevails in urban settings, it has also spread to rural areas, where the ratio of farmers to extension workers exceeds 1000 to one [75,84-86]. Moreover, with increased physical restrictions from COVID-19, there is a need to reach and engage with farmers using innovative technologies. This opportunity might represent a transition for games in agriculture. Similar to how massive data sets' availability was critical to turning attention toward specific areas of labor and industrial organization in the past [2], big data and games can switch attention toward agriculture. Overall, conducting games and fieldwork in agriculture demands managing complex sets of relationships between parties and presenting and communicating ideas and innovation to lay individuals [3,87]. These characteristics define researchers' value leading games and fieldwork in agriculture to respond to today's challenges. 
The growing popularity of coordination and cooperation games involving groups rather than individuals is consistent with a greater focus on natural resource management, conservation, and ecology—areas that depend on collective decisions. The games evaluated here primarily assessed contributions to public goods and the determinants of cooperation for land use, water management, biodiversity, ecosystem services, and organizational aspects. For instance, several studies from East Asia documented how serious games could be used to resolve commons management issues in fishing communities. Most Europe based studies reported how simulation exercises could be used to make a business case for conservation agriculture in specific industries (e.g., [17,32,34]). These new questions and focus areas did not replace, however, traditional games and settings during the last twenty years. Market games and simulations-which have been common in South and Southeast Asia-reflect a longstanding interest in understanding individual and collective behaviors in the context of farm risk and inputs management $[7,35,37,44]$. Canonical experimental games to understand social preferences and trust, including the ultimatum game and the dictator game, and lottery games to assess risk behavior [88], were also performed in more diverse contexts, including ecosystem services and natural resource management $[46,63]$. Moreover, the increased use of primary data and lottery games to elicit risk preferences in diverse context—also reported in other reviews [10]—reflect the need to control for the environment in which farmers operate, and that risk aversion is a relative concept likely to be circumstance specific [10]. In brief, and although not perceived as "innovative", the frequency of canonical games suggest that they became a standard to support research in traditional and new areas for sustainable agriculture.

The attention toward sustainable agriculture and the particular emphasis on the environmental dimension coincides with recent policy-oriented reviews that highlight the increased interest in understanding behavioral factors influencing farmers' adoption of sustainable practices [7,8,89]. A meta-analysis is out of this paper's scope. The influence of many external factors, such as cultural background or location, increases the challenge of aggregating farmers' preferences across a larger geographical region [10]. From Table 1, we can see some consistent themes emerging. For instance, questions related to payments and markets for ecosystem services, forestry, and gender differences increased, especially after $2015[36,41,58]$ and those empirical observations corroborated the role of voluntary and mandatory policies for conservation based on farmer's dispositional factors such as environmental concerns and risk tolerance reported in other studies [8,10]. In addition, the papers analyzed in our sample suggest-as do other studies-that farmers with intrinsic motivations to protect the environment do not necessarily react negatively to extrinsic motivators and conservation payments [8]. Overall, the rising interest in sustainability during the last twenty years [90] was reflected in the higher frequency of cooperation games and other canonical games that took place in strategic regions in terms of diversity, natural resources, and poverty.

\section{Conclusions and Future Directions}

The 21st century has witnessed a significant surge in studies that are gathering data via games, and agriculture is not an exception. There is an increased emphasis on agricultural sustainability in Africa, Asia, and Latin America and a higher frequency of cooperation and coordination games that reflect collective decisions for conservation and natural resource management. Other canonical games related to social preferences, i.e., trust games, and individual decision making, i.e., risk games, also remain prominent in the field. There is ample opportunity to scale existing games, improve their validity by conducting games in multiple contexts and with various populations, and repeat and monitor games and subjects over time. New technologies for data will play an essential role in the purpose of improving identification strategies. Judging by the low but increasing percentage of games using digital tools in agriculture, it is possible that gamification will play a role in the way that games are designed and implemented for experimental and educational purposes. Emerging topics in conservation and climate risk will likely shape the agenda in the coming years. Applied economists and social scientists are called to be part of this challenging and exciting agenda by scaling existing 
studies, incentivizing participation of excluded populations with engaging and innovative games, and embracing the information communication technologies of this century.

Author Contributions: Conceptualization, methodology, and software, J.N.H.-A., M.M., A.H., and D.O. All authors contributed to the review validation, formal analysis, investigation, writing, draft preparation and editing. All authors have read and agreed to the published version of the manuscript.

Funding: This research was partially funded by the Earth Institute Columbia University and Columbia World Projects, ACToday.

Acknowledgments: We acknowledge the comments and the support received by the Financial Instrument Sector Team (FIST) at the International Research Institute for Climate and Society.

Conflicts of Interest: The authors declare no conflict of interest. The funders had no role in the design of the study; in the collection, analyses, or interpretation of data; in the writing of the manuscript, or in the decision to publish the results.

\section{Appendix A}

Table A1. Literature review categories.

\begin{tabular}{|c|c|}
\hline \multicolumn{2}{|c|}{ Q1: What Is the Primary Purpose and Context of Games in Agriculture in This Period? } \\
\hline Subject & Individual, group, both \\
\hline Agriculture sector & Growing crops, raising animals, fishery, forestry, hunting, farming \\
\hline Region & $\begin{array}{l}\text { North Africa, East Africa, Central Africa, East Asia, South Asia, Southeast Asia, West Asia, } \\
\text { North Asia, Latina America, USA/Canada, Europe, Australia }\end{array}$ \\
\hline Thematic domain & $\begin{array}{l}\text { Altruism, reciprocity, trust, fairness, other social preferences, public good games, other } \\
\text { coordination and cooperation, market games and simulations (e.g., willingness to pay), } \\
\text { risk preferences/attitudes, memory, intertemporal behavior/discounting, technology } \\
\text { adoption/acceptance, other behavior and cognitive bias }\end{array}$ \\
\hline Production/management context & $\begin{array}{l}\text { Financial and risk management, climate risk and natural disasters, natural resource } \\
\text { management: water, natural resource management: land, natural resource management: } \\
\text { other, conservation and biodiversity, ecosystem services and agroecological practices, } \\
\text { inputs management (e.g., tools and fertilizers), pest control and management, inclusion } \\
\text { and gender issues, health and nutrition/food security, human capital/education, } \\
\text { organizational aspects/cooperatives, social capital/community engagement, business } \\
\text { strategies and value chains, property rights, regulation/policies }\end{array}$ \\
\hline \multicolumn{2}{|c|}{ Q2: What is the Scope of the Game's Results and Conclusions Based on the Experimental Design? } \\
\hline Number of participants & $\begin{array}{l}1 \text { to } 10 ; 11 \text { to } 50 ; 51 \text { to } 100 ; 101 \text { to } 300 ; 301 \text { to } 600 ; 601 \text { to } 1000 ; 1001 \text { to } 3000 ; 3001 \text { to } 6000 ; 6001 \\
\text { to } 10,000 ; 10,001 \text { to } 50,000 ; 50,001 \text { to } 100,000 ; \text { more than } 100,000 \text { but less than one million; } \\
\text { one million or more. }\end{array}$ \\
\hline Validity assessment & $\begin{array}{l}\text { High: Randomized control trial experiments in the field with real-world outcomes. } \\
\text { Medium: Quasi-experimental controlled studyLow: Case study, single } \\
\text { subject-experimental, pre-test/post-test design. Evident confounding factors (yes/no). }\end{array}$ \\
\hline Robustness indicators & $\begin{array}{l}\text { Reported power calculation to estimate sample size (yes/no); experiment duration (hours, } \\
\text { days, weeks, months); experiment repetition (rounds on the game, whole game, no } \\
\text { repetition). }\end{array}$ \\
\hline Balance indicators & $\begin{array}{l}\text { Gender balance (yes/no/no reported); different ages (yes/no/no reported); different } \\
\text { ethnicities (yes/no/no reported). }\end{array}$ \\
\hline Incentives & $\begin{array}{l}\text { Actual monetary incentives, simulated monetary incentives, other extrinsic incentives; } \\
\text { intrinsic incentives; both (intrinsic and extrinsic). }\end{array}$ \\
\hline \multicolumn{2}{|c|}{$\begin{array}{c}\text { Q3: Is There Evidence of Any Technological Transition or Evolution in the Way That Games and Experiments Have Been } \\
\text { Performed and Implemented in Rural Settings? }\end{array}$} \\
\hline Setting: facilitator & $\begin{array}{l}\text { Researchers' leading workshops/games; extension service or local collaborators facilitating } \\
\text { workshops/games; digital tool or information technology (IT) for end-users (farmers); } \\
\text { digital tool or IT administered by local collaborators/extension services. }\end{array}$ \\
\hline Setting: modality & Paper-based, cell phone/SMS; smartphone/apps; web-based software/tablets/computer. \\
\hline Continued assessment & $\begin{array}{l}\text { The game can eventually be shared by initial participants with other potential players on } \\
\text { their communities (yes/no). There is opportunity to continuing data gathering after the } \\
\text { game/experiment is introduced and performed for the first time (yes/no). The } \\
\text { experiment/game facilitate feedback opportunities along the time (yes/no). }\end{array}$ \\
\hline
\end{tabular}

In addition to these specific categories, the reviewers' analysis included identification of research question, main hypothesis, major result and additional comments. 
Table A2. Research scope normalization coding scheme.

\begin{tabular}{ll}
\hline \multicolumn{1}{c}{ Outcome } & \multicolumn{1}{c}{ Coding } \\
\hline Sample size & 11 to $50=0.2 ; 50$ to $100=0.4 ; 100$ to $300=0.6 ; 300$ to $600=0.8 ;$ more than \\
$600=1$
\end{tabular}

Scope score $=1 / 2($ sample size $+1 / 3($ gender balance + ethnic balance + age balance $))+1 / 2($ repetition + incentives $)+$ $1 / 2$ (validity + evident confounding factors).

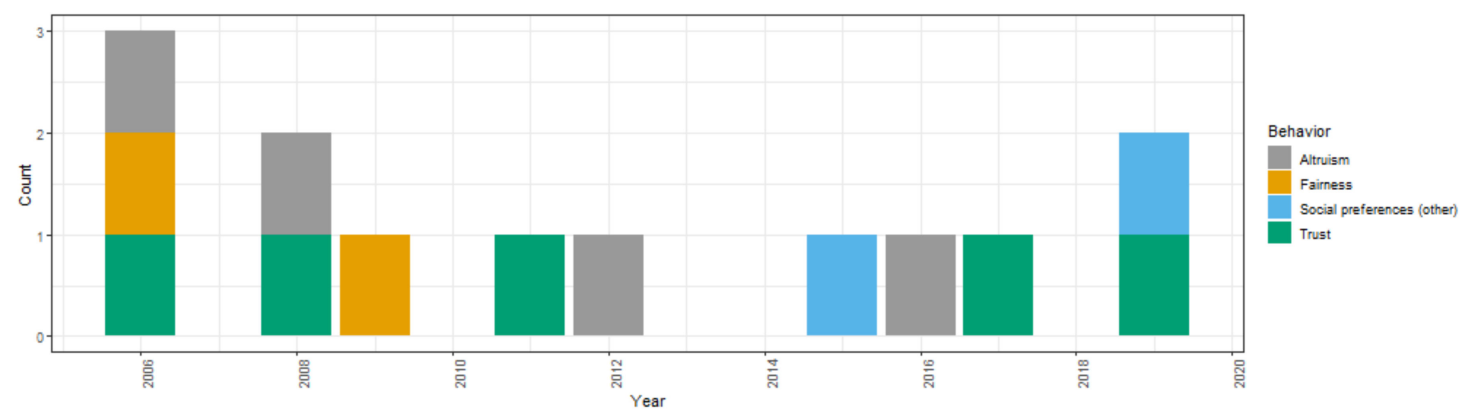

Figure A1. Frequency of social preference studies by type.

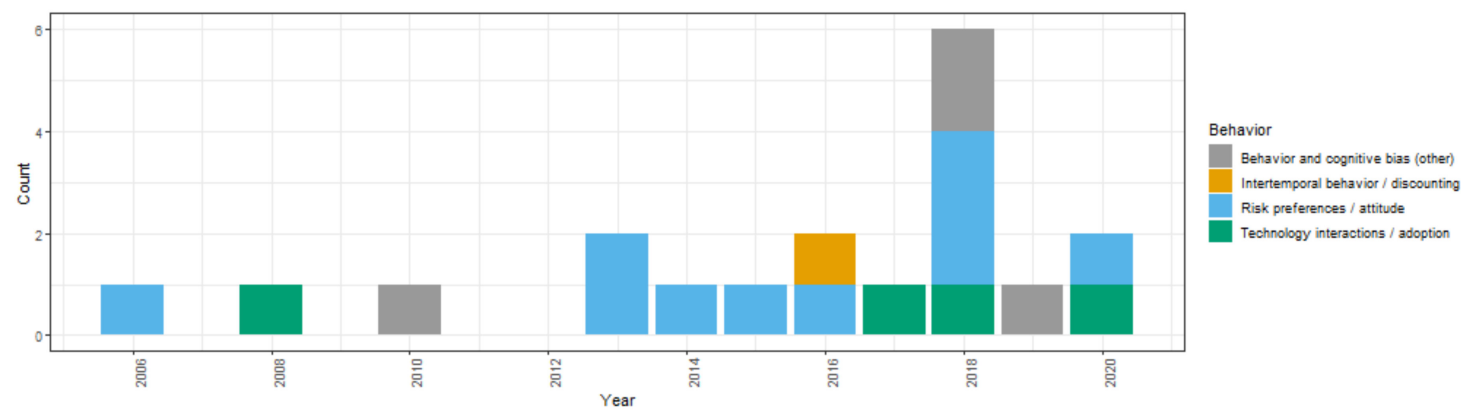

Figure A2. Frequency of behavioral and cognitive bias studies by type.

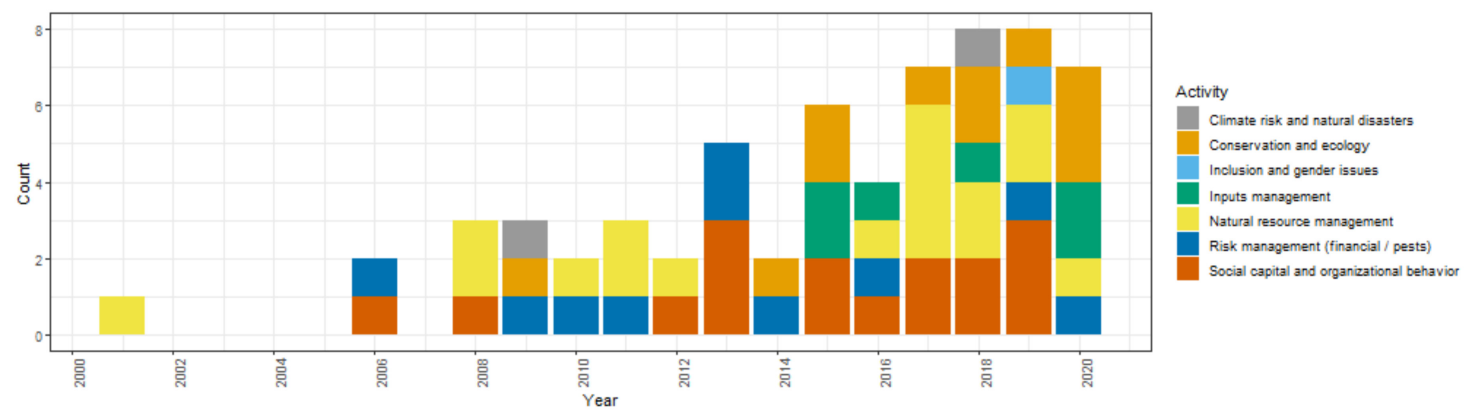

Figure A3. Frequency of studies by activity focus over years. 


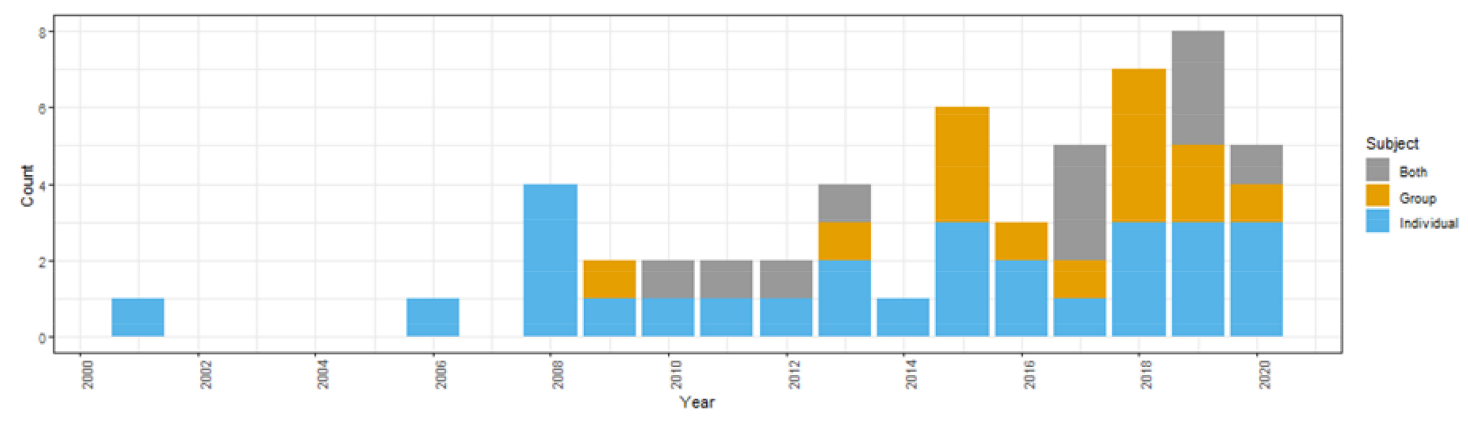

Figure A4. Frequency of studies by subject (individuals, groups, both) over years.

\section{References}

1. Mendler de Suarez, J.; Suarez, J.; Suarez, P.; Bachofen, C.; Fortungo, N.; Goentzel, J. Games for a New Climate: Experiencing the Complexity of Future Risks; Frederick, S., Ed.; Pardee Center for the Study of the Longer-Range Future: Boston, MA, USA, 2012; ISBN 978-1-936727-06-3.

2. Herberich, D.H.; Levitt, S.D.; List, J.A. Can Field Experiments Return Agricultural Economics to the Glory Days? Am. J. Agric. Econ. 2009, 91, 1259-1265. [CrossRef]

3. List, J.A.; Metcalfe, R. Field experiments in the developed world: An introduction. Oxf. Rev. Econ. Policy 2014, 30, 585-596. [CrossRef]

4. Harrison, G.W.; List, J.A. Field Experiments. J. Econ. Lit. 2004, 42, 1009-1055. [CrossRef]

5. Deaton, A. Instruments, Randomization, and Learning about Development. J. Econ. Lit. 2010, 48, 424-455. [CrossRef]

6. Deaton, A.; Cartwright, N. Understanding and misunderstanding randomized controlled trials. Soc. Sci. Med. 2018, 210, 2-21. [CrossRef]

7. Colen, L.; Gomez y Paloma, S.; Latacz-Lohmann, U.; Lefebvre, M.; Preget, R.; Thoyer, S. Economic Experiments as a Tool for Agricultural Policy Evaluation: Insights from the European CAP. Can. J. Agric. Econ. 2016, 64, 667-694. [CrossRef]

8. Dessart, F.J.; Barreiro-Hurlé, J.; van Bavel, R. Behavioural factors affecting the adoption of sustainable farming practices: A policy-oriented review. Eur. Rev. Agric. Econ. 2019, 46, 417-471. [CrossRef]

9. Viceisza, A.C.G. Creating a Lab in the Field: Economics Experiments for Policymaking. J. Econ. Surv. 2016, 30, 835-854. [CrossRef]

10. Iyer, P.; Bozzola, M.; Hirsch, S.; Meraner, M.; Finger, R. Measuring Farmer Risk Preferences in Europe: A Systematic Review. J. Agric. Econ. 2020, 71, 3-26. [CrossRef]

11. Moher, D.; Liberati, A.; Tetzlaff, J.; Altman, D.G. Preferred Reporting Items for Systematic Reviews and Meta-Analyses: The PRISMA Statement. J. Clin. Epidemiol. 2009, 62, 1006-1012. [CrossRef]

12. Matthews, T. LibGuides: Web of Science platform: Web of Science: Summary of Coverage. Available online: https://clarivate.libguides.com/webofscienceplatform/coverage (accessed on 31 July 2020).

13. What Is Scopus Preview? Scopus: Access and Use Support Center. Available online: https://service.elsevier. com/app/answers/detail/a_id/15534/supporthub/scopus/\#tips (accessed on 31 July 2020).

14. Wittgren, H.B.; Castensson, R.; Gipperth, L.; Joelsson, A.; Jonasson, L.; Pettersson, A.; Thunvik, R.; Torstensson, G. An actor game on implementation of environmental quality standards for nitrogen in a Swedish agricultural catchment. Ambio 2005, 34, 237-247. [CrossRef] [PubMed]

15. Vasilaky, K.N.; Brock, J.M. Power(ful) Guidelines for Experimental Economists; Social Science Research Network: Rochester, NY, USA, 2020.

16. Sawada, Y.; Kasahara, R.; Aoyagi, K.; Shoji, M.; Ueyama, M. Modes of collective action in village economies: Evidence from natural and artefactual field experiments in a developing country. Asian Dev. Rev. 2013, 30, 31-51. [CrossRef]

17. Doerschner, T.; Musshoff, O. How do incentive-based environmental policies affect environment protection initiatives of farmers? An experimental economic analysis using the example of species richness. Ecol. Econ. 2015, 114, 90-103. [CrossRef] 
18. Voors, M.; Turley, T.; Kontoleon, A.; Bulte, E.; List, J.A. Exploring whether behavior in context-free experiments is predictive of behavior in the field: Evidence from lab and field experiments in rural Sierra Leone. Econ. Lett. 2012, 114, 308-311. [CrossRef]

19. Tsusaka, T.W.; Kajisa, K.; Pede, V.O.; Aoyagi, K. Neighborhood effects and social behavior: The case of irrigated and rainfed farmers in Bohol, the Philippines. J. Econ. Behav. Organ. 2015, 118, 227-246. [CrossRef]

20. Marrocoli, S.; Gatiso, T.T.; Morgan, D.; Nielsen, M.R.; Kuehl, H. Environmental Uncertainty and Self-monitoring in the Commons: A Common-pool Resource Experiment Framed Around Bushmeat Hunting in the Republic of Congo. Ecol. Econ. 2018, 149, 274-284. [CrossRef]

21. Singerman, A.; Useche, P. The Role of Strategic Uncertainty in Area-wide Pest Management Decisions of Florida Citrus Growers. Am. J. Agric. Econ. 2019, 101, 991-1011. [CrossRef]

22. Peth, D.; Musshoff, O. Comparing Compliance Behaviour of Students and Farmers. An Extra-laboratory Experiment in the Context of Agri-environmental Nudges in Germany. J. Agric. Econ. 2020, 71, 601-615. [CrossRef]

23. Midler, E.; Pascual, U.; Drucker, A.G.; Narloch, U.; Soto, J.L. Unraveling the effects of payments for ecosystem services on motivations for collective action. Ecol. Econ. 2015, 120, 394-405. [CrossRef]

24. Maligalig, R.; Demont, M.; Umberger, W.J.; Peralta, A. Off-farm employment increases women's empowerment: Evidence from rice farms in the Philippines. J. Rural. Stud. 2019, 71, 62-72. [CrossRef]

25. Francesconi, G.N.; Wouterse, F. The Health of Farmer-Based Organisations in Ghana: Organisational Diagnostics and Governance Implications. J. Dev. Stud. 2015, 51, 262-273. [CrossRef]

26. Hopfensitz, A.; Miquel-Florensa, J. Mill ownership and farmer's cooperative behavior: The case of Costa Rica coffee farmers. J. Inst. Econ. 2017, 13, 623-648. [CrossRef]

27. Hayo, B.; Vollan, B. Group interaction, heterogeneity, rules, and co-operative behaviour: Evidence from a common-pool resource experiment in South Africa and Namibia. J. Econ. Behav. Organ. 2012, 81, 9-28. [CrossRef]

28. Ibele, B.; Sandri, S.; Zikos, D. Endogenous Versus Exogenous Rules in Water Management: An Experimental Cross-country Comparison. Mediterr. Politics 2017, 22, 504-536. [CrossRef]

29. Msaddak, M.; Ben-Nasr, J.; Zaibet, L. Resolving Recurrent Imperfections in the Dairy Production Using Gaming Simulation. New Medit 2019, 18, 35-49. [CrossRef]

30. Barreteau, O.; Bousquet, F.; Attonaty, J.-M. Role-Playing Games for Opening the Black Box of Multi-Agent Systems: Method and Lessons of Its Application to Senegal River Valley Irrigated Systems. J. Artif. Soc. Soc. Simul. 2001, 4, 1-5.

31. García-Barrios, L.; García-Barrios, R.; Waterman, A.; Cruz-Morales, J. Social Dilemmas and Individual/Group Coordination Strategies in a Complex Rural Land-Use Game. Int. J. Commons 2011, 5, 364-387. [CrossRef]

32. Moreau, C.; Barnaud, C.; Mathevet, R. Conciliate agriculture with landscape and biodiversity conservation: A role-playing game to explore trade-offs among ecosystem services through social learning. Sustainability 2019, 11, 310. [CrossRef]

33. Hardy, P.-Y.; Dray, A.; Cornioley, T.; David, M.; Sabatier, R.; Kernes, E.; Souchère, V. Public Policy Design: Assessing the Potential of New Collective Agri-Environmental Schemes in the Marais Poitevin Wetland Region Using a Participatory Approach. Land Use Policy 2020, 97, 104724. [CrossRef]

34. Sausse, C.; Le Bail, M.; Lecroart, B.; Remy, B.; Messéan, A. How to manage the coexistence between genetically modified and conventional crops in grain and oilseed collection areas? Elaboration of scenarios using role playing games. Land Use Policy 2013, 30, 719-729. [CrossRef]

35. Moser, S.; Musshoff, O. Ex-ante Evaluation of Policy Measures: Effects of Reward and Punishment for Fertiliser Reduction in Palm Oil Production. J. Agric. Econ. 2016, 67, 84-104. [CrossRef]

36. Kaczan, D.J.; Swallow, B.M.; Adamowicz, W.L. (Vic) Forest conservation policy and motivational crowding: Experimental evidence from Tanzania. Ecol. Econ. 2019, 156, 444-453. [CrossRef]

37. Seth, R.; Ansari, V.A.; Datta, M. Weather-risk hedging by farmers: An empirical study of willingness-to-pay in Rajasthan, India. J. Risk Financ. 2009, 10, 54-66. [CrossRef]

38. Norton, M.; Osgood, D.; Madajewicz, M.; Holthaus, E.; Peterson, N.; Diro, R.; Mullally, C.; Teh, T.-L.; Gebremichael, M. Evidence of Demand for Index Insurance: Experimental Games and Commercial Transactions in Ethiopia. J. Dev. Stud. 2014, 50, 630-648. [CrossRef] 
39. Vasilaky, K.; Diro, R.; Norton, M.; McCarney, G.; Osgood, D. Can Education Unlock Scale? The Demand Impact of Educational Games on a Large-Scale Unsubsidised Index Insurance Programme in Ethiopia. J. Dev. Stud. 2020, 56, 361-383. [CrossRef]

40. Patt, A.; Suarez, P.; Hess, U. How do small-holder farmers understand insurance, and how much do they want it? Evidence from Africa. Glob. Environ. Chang. 2010, 20, 153-161. [CrossRef]

41. Leimona, B.; Carrasco, L.R. Auction winning, social dynamics and non-compliance in a payment for ecosystem services scheme in Indonesia. Land Use Policy 2017, 63, 632-644. [CrossRef]

42. Merlet, P.; Van Hecken, G.; Rodriguez-Fabilena, R. Playing before paying? A PES simulation game for assessing power inequalities and motivations in the governance of Ecosystem Services. Ecosyst. Serv. 2018, 34, 218-227. [CrossRef]

43. Berthet, E.T.A.; Barnaud, C.; Girard, N.; Labatut, J.; Martin, G. How to Foster Agroecological Innovations? A Comparison of Participatory Design Methods. J. Environ. Plan. Manag. 2016, 59, 280-301. [CrossRef]

44. Bos, S.P.M.; Cornioley, T.; Dray, A.; Waeber, P.O.; Garcia, C.A. Exploring livelihood strategies of shifting cultivation farmers in assam through games. Sustainability 2020, 12, 2438. [CrossRef]

45. Peth, D.; Musshoff, O.; Funke, K.; Hirschauer, N. Nudging Farmers to Comply with Water Protection Rules —Experimental Evidence From Germany. Ecol. Econ. 2018, 152, 310-321. [CrossRef]

46. Moros, L.; Velez, M.A.; Corbera, E. Payments for Ecosystem Services and Motivational Crowding in Colombia's Amazon Piedmont. Ecol. Econ. 2019, 156, 468-488. [CrossRef]

47. Schechter, L. Trust, trustworthiness, and risk in rural Paraguay. Exp. Econ. 2006, 9, 173. [CrossRef]

48. Brick, K.I.; Visser, M. Risk preferences, technology adoption and insurance uptake: A framed experiment. J. Econ. Behav. Organ. 2015, 118, 383-396. [CrossRef]

49. Khor, L.Y.; Ufer, S.; Nielsen, T.; Zeller, M. Impact of risk aversion on fertiliser use: Evidence from Vietnam. Oxf. Dev. Stud. 2018, 46, 483-496. [CrossRef]

50. Katic, P.; Ellis, T. Risk aversion in agricultural water management investments in Northern Ghana: Experimental evidence. Agric. Econ. 2018, 49, 575-586. [CrossRef]

51. Barnaud, C.; van Paassen, A.; Trébuil, G.; Promburom, T.; Bousquet, F. Dealing with power games in a companion modelling process: Lessons from community water management in Thailand highlands. J. Agric. Educ. Ext. 2010, 16, 55-74. [CrossRef]

52. Ye, T.; Wang, M. Exploring risk attitude by a comparative experimental approach and its implication to disaster insurance practice in China. J. Risk Res. 2013, 16, 861-878. [CrossRef]

53. Marenya, P.; Smith, V.H.; Nkonya, E. Relative Preferences for Soil Conservation Incentives among Smallholder Farmers: Evidence from Malawi. Am. J. Agric. Econ. 2014, 96, 690-710. [CrossRef]

54. Lebel, L.; Lebel, P. Emotions, attitudes, and appraisal in the management of climate-related risks by fish farmers in Northern Thailand. J. Risk Res. 2018, 21, 933-951. [CrossRef]

55. Nielsen, T.; Keil, A.; Zeller, M. Assessing farmers' risk preferences and their determinants in a marginal upland area of Vietnam: A comparison of multiple elicitation techniques. Agric. Econ. 2013, 44, 255-273. [CrossRef]

56. Bosma, R.H.; Ha, T.T.P.; Hiep, T.Q.; Phuong, N.T.H.; Ligtenberg, A.; Rodela, R.; Bregt, A.K. Changing opinion, knowledge, skill and behaviour of Vietnamese shrimp farmers by using serious board games. J. Agric. Educ. Ext. 2020, 26, 203-221. [CrossRef]

57. Dionnet, M.; Kuper, M.; Hammani, A.; Garin, P. Combining role-playing games and policy simulation exercises: An experience with Moroccan smallholder farmers. Simul. Gaming 2008, 39, 498-514. [CrossRef]

58. Villamor, G.B.; Catacutan, D.C.; Truong, V.A.T.; Thi, L.D. Tree-cover transition in Northern Vietnam from a gender-specific land-use preferences perspective. Land Use Policy 2017, 61, 53-62. [CrossRef]

59. Mueller, M.; Rommel, J.; Kimmich, C. Farmers' Adoption of Irrigation Technologies: Experimental Evidence from a Coordination Game with Positive Network Externalities in India. Ger. Econ. Rev. 2018, 19, 119-139. [CrossRef]

60. Gobien, S.; Vollan, B. Exchanging Land for Solidarity: Solidarity Transfers among Voluntarily Resettled and Non-resettled Land-Reform Beneficiaries. Am. J. Agric. Econ. 2016, 98, 802-818. [CrossRef]

61. Buck, S.; Alwang, J. Agricultural extension, trust, and learning: Results from economic experiments in Ecuador. Agric. Econ. 2011, 42, 685-699. [CrossRef]

62. Bouma, J.; Bulte, E.; van Soest, D. Trust and cooperation: Social capital and community resource management. J. Environ. Econ. Manag. 2008, 56, 155-166. [CrossRef] 
63. Ansink, E.; Tesfaye, A.; Bouma, J.; Brouwer, R. Cooperation in watershed management: A field experiment on location, trust, and enforcement. Resour. Energy Econ. 2017, 50, 91-104. [CrossRef]

64. Romero Granja, C.; Wollni, M. Opportunistic Behaviour and Trust: Experimental Results from Broccoli Farmers in Ecuador. J. Agric. Econ. 2019, 70, 62-80. [CrossRef]

65. Aksoy, B.; Palma, M.A. The effects of scarcity on cheating and in-group favoritism. J. Econ. Behav. Organ. 2019, 165, 100-117. [CrossRef]

66. Bharwani, S.; Besa, M.C.; Taylor, R.; Fischer, M.; Devisscher, T.; Kenfack, C. Identifying Salient Drivers of Livelihood Decision-Making in the Forest Communities of Cameroon: Adding Value to Social Simulation Models. JASSS J. Artif. Soc. Soc. Simul. 2015, 18. [CrossRef]

67. Gumucio, T.; Hansen, J.; Huyer, S.; van Huysen, T. Gender-responsive rural climate services: A review of the literature. Clim. Dev. 2020, 12, 241-254. [CrossRef]

68. Angrist, J.D.; Pischke, J.-S. Mostly Harmless Econometrics: An Empiricist's Companion; Princeton University Press: Princeton, NJ, USA, 2008; ISBN 978-1-4008-2982-8.

69. Ravallion, M. Should the Randomistas (Continue to) Rule? Working Paper Series; National Bureau of Economic Research: Cambridge, MA, USA, 2020.

70. Olken, B.A. Promises and Perils of Pre-Analysis Plans. J. Econ. Perspect. 2015, 29, 61-80. [CrossRef]

71. Cilliers, J.; Dube, O.; Siddiqi, B. The white-man effect: How foreigner presence affects behavior in experiments. J. Econ. Behav. Organ. 2015, 118, 397-414. [CrossRef]

72. Benz, M.; Meier, S. Do people behave in experiments as in the field?-Evidence from donations. Exp. Econ. 2008, 11, 268-281. [CrossRef]

73. Fehr, E.; Gachter, S. Altruistic punishment in humans. Nat. Lond. 2002, 415, 137-140. [CrossRef]

74. Rustagi, D.; Engel, S.; Kosfeld, M. Conditional Cooperation and Costly Monitoring Explain Success in Forest Commons Management. Science 2010, 330, 961-965. [CrossRef]

75. Fielke, S.; Taylor, B.; Jakku, E. Digitalisation of agricultural knowledge and advice networks: A state-of-the-art review. Agric. Syst. 2020, 180, 102763. [CrossRef]

76. Rosmansyah, Y.; Achiruzaman, M.; Hardi, A.B. A 3D multiuser virtual learning environment for online training of agriculture surveyors. J. Inf. Technol. Educ. Res. 2019, 18. [CrossRef]

77. Hernandez-Aguilera, J.N.; Mauerman, M.; Osgood, D. Playing to Adapt: Crowdsourcing Historical Climate Data with Gamification to Improve Farmer's Risk Management Instruments; Social Science Research Network: Rochester, NY, USA, 2020.

78. Sutoyo, M.A.H.; Sensuse, D.I. Designing a Conceptual Model for Rice Information Systems using Gamification and Soft System Methodology. In Proceedings of the 2018 International Conference on Advanced Computer Science and Information Systems (ICACSIS), Yogyakarta, Indonesia, 27-28 October 2018; pp. $63-68$.

79. García-Barrios, L.; Perfecto, I.; Vandermeer, J. Azteca chess: Gamifying a complex ecological process of autonomous pest control in shade coffee. Agric. Ecosyst. Environ. 2016, 232, 190-198. [CrossRef]

80. Haag, M.; LeTourneau, J.; Marra, R.; Patterson, D.; Smith, M.; Lamberson, W. The effectiveness of a gamified, online, beef cattle breeding simulation to increase student engagement, motivation, and learning gains. J. Anim. Sci. Champaign 2018, 96, 499. [CrossRef]

81. Johnson, D.; Deterding, S.; Kuhn, K.-A.; Staneva, A.; Stoyanov, S.; Hides, L. Gamification for health and wellbeing: A systematic review of the literature. Internet Interv. 2016, 6, 89-106. [CrossRef]

82. Cugelman, B. Gamification: What it is and why it matters to digital health behavior change developers. JMIR Serious Games 2013, 1, e3. [CrossRef]

83. Hervas, R.; Ruiz-Carrasco, D.; Mondejar, T.; Bravo, J. Gamification Mechanics for Behavioral Change: A Systematic Review and Proposed Taxonomy. In Proceedings of the 11th EAI International Conference on Pervasive Computing Technologies for Healthcare, Barcelona, Spain, 23-26 May 2017; pp. 395-404.

84. The World Bank. World Development Report 2016: Digital Dividends; World Bank Publications: Washington, DC, USA, 2016; ISBN 978-1-4648-0671-1.

85. Deichmann, U.; Goyal, A.; Mishra, D. Will Digital Technologies Transform Agriculture in Developing Countries? Policy Research Working Papers; The World Bank: Washington, DC, USA, 2016.

86. Fabregas, R.; Kremer, M.; Schilbach, F. Realizing the potential of digital development: The case of agricultural advice. Science 2019, 366. [CrossRef]

87. List, J.A. Why Economists Should Conduct Field Experiments and 14 Tips for Pulling One Off. J. Econ. Perspect. 2011, 25, 3-16. [CrossRef] 
88. Berg, J.; Dickhaut, J.; McCabe, K. Trust, Reciprocity, and Social History. Games Econ. Behav. 1995, 10, $122-142$. [CrossRef]

89. The World Bank. World Development Report 2015: Mind, Society, and Behavior; The World Bank: Washington, DC, USA, 2015. [CrossRef]

90. Soderbaum, P. Understanding Sustainability Economics: Towards Pluralism in Economics; Routledge: Abingdon-on-Thames, UK, 2012; ISBN 978-1-136-54964-9.

Publisher's Note: MDPI stays neutral with regard to jurisdictional claims in published maps and institutional affiliations.

(C) 2020 by the authors. Licensee MDPI, Basel, Switzerland. This article is an open access article distributed under the terms and conditions of the Creative Commons Attribution (CC BY) license (http://creativecommons.org/licenses/by/4.0/). 